\title{
One Day Service dalam Isbat Nikah Terpadu Bagi Penduduk Marjinal di Kecamatan Paliyan Tahun 2015 - 2019
}

\section{One Day Service in Integrated Marriage Determination for Marjinal Population in Paliyan District 2015 - 2019}

\author{
Sabit Mustamil \\ Kantor Urusan Agama Kecamatan Patuk \\ Kementerian Agama Kabupaten Gunungkidul Daerah Istimewa Yogyakarta \\ Email: mustamil71@gmail.com \\ Artikel diterima 14 Oktober 2019, diseleksi 30 November 2019, \\ dan disetujui 11 Desember 2019
}

Abstrak: Penelitian ini bertujuan untuk mendeskripsikan faktor-faktor yang menyebabkan pernikahan tidak tercatat, peran penghulu dalam menyelesaikan pernikahan yang tidak tercatat, dan solusi hukum atas pernikahan yang tidak tercatat di sebagian masyarakat Kecamatan Paliyan.Metode penelitian yang digunakan adalah deskriptif kualitatif. Penggalian data dilakukan dengan wawancara, dokumentasi dan observasi di desa yang menjadi tempat pelaksanaan one day service dalam isbat nikah terpadu bagi penduduk marjinal di Kecamatan Paliyan. Adapun yang menjadi informan dalam penelitian ini adalah pegawai KUA, PA, Dukcapil, Kasi Pelayanan Desa, Pendamping Keluarga Harapan (PKH), dan Dukuh serta peserta one day service dalam isbat nikah bagi pennduduk marjinal di Kecamatan Paliyan.Hasil penelitian menunjukkan bahwa belo nikah, kerubuhan gunung, lokasi yang jauh dan berbukit, kesadaran masyarakat rendah dan kurangnya pengawasan merupakan faktor-faktor yang menyebabkan pernikahan tidak tercatat.

Kata kunci: pernikahan, isbat nikah, dan one day service 
Abstrct: This study aims to describe the factors that cause unregistered marriages, the role of princes in completing unregistered marriages, and legal solutions to unregistered marriages in some communities in the Paliyan District. The research method used is descriptive qualitative. Data mining was carried out by interviewing, documenting and observing in the village where one day service was carried out in an integrated marriage for marginal residents in the Paliyan District. As for the informants in this study were employees of KUA, PA, Dukcapil, Head of Village Services, Hope Family Assistance (PKH), and Hamlet as well as one day service participants in marriage isbat for marginalized residents in Paliyan District.The results showed that marriage belo, mountain collapse, distant and hilly locations, low public awareness and lack of supervision are factors that cause unregistered marriages.

Keywords: marriage, marriage determination, and one day service

\section{A. Pendahuluan}

Perkawinan adalah ikatan lahir batin antara seorang laki-laki dan seorang perempuan sebagai suami isteri dengan tujuan membentuk keluarga yang bahagia dan kekal berdasarkan Ketuhanan Yang Maha Esa. ${ }^{1}$ Untuk menjamin tujuan perkawinan tersebut maka Undang-Undang Perkawinan menetapkan adanya pencatatan perkawinan ${ }^{2}$. Kompilasi Hukum Islam memperkuat arti pentingnya pencatatan demi ketertiban dan kemaslahatan bersama, sehingga mewajibkan adanya pencatatan pernikahan oleh lembaga resmi pemerintah untuk menghindari segala bentuk efek negatif yang mungkin akan terjadi. ${ }^{3}$ Implikasinya, setiap perkawinan yang dilakukan di luar pengawasan Pegawai Pencatat Nikah tidak mempunyai kekuatan hukum yang tetap karena tidak ada bukti autentik.

Fakta empiris yang terjadi di Kabupaten Gunungkidul pada rentang tahun 1960 sampai dengan tahun 1980, ditemukan 3,03 persen (6.191 
keluarga) tidak mempunyai buku nikah. Data ketiadaan buku nikah tertinggi ada di Kecamatan Paliyan, yaitu 9,27 persen (dari 8.610 keluarga, 798 di antaranya tidak mempunyai buku nikah).

Ketiadaan buku nikah diduga akibat dari pernikahan yang tidak tercatat. Tidak tercatatnya peristiwa pernikahan itu terjadi bukan sematamata karena keteledoran Penghulu, tetapi para pihak yaitu calon suami isteri, tokoh masyarakat dan perangkat desa saat itu juga ikut andil dalam menyebabkan tidak tercatatnya pernikahan tersebut. Kondisi wilayah yang jauh dan berbukit juga ikut memperparah keadaan ini. Ketertiban administrasi pada saat itu belum menjadi prioritas utama dan sebagian petugas belum memahami sepenuhnya akibat hukum dari tidak tercatatnya pernikahan.

Pernikahan yang tidak tercatat menimbulkan banyak masalah, di antaranya tidak adanya legitimasi hukum, tidak adanya perlindungan hukum dalam keluarga khususnya isteri dan anak, ${ }^{4}$ kehilangan hakhak sipil seperti penerbitan Kartu Keluarga, Kartu Tanda Penduduk Elektronik, Akta kelahiran dan data-data kependudukan lain yang terkait dengan buku nikah. Perkawinan yang tidak tercatat dapat merugikan kepentingan keluarga dan mengganggu pemenuhan, perlindungan, dan penegakan hak anak. Sebagai peristiwa hukum, perkawinan tentu terkait langsung dengan anak-anak yang dilahirkan, baik dalam hukum keluarga maupun hak-hak anak yang dijamin oleh hak asasi manusia (child's rights are humanrights). ${ }^{5}$

Isbat nikah adalah salah satu solusi untuk mendapatkan buku nikah bagi pasangan yang pernikahannya tidak tercatat. Namun yang menjadi persoalan berikutnya adalah banyak ditemukan pasangan yang tidak mempunyai buku nikah berasal dari penduduk marjinal yang keadaannya miskin, berpendidikan rendah dan pengetahuan tentang hukum sangat kurang. Proses permohonan isbat nikah yang panjang dan melibatkan banyak pihak sehingga menyulitkan penduduk marjinal jika dilaksanakan mandiri. Untuk itulah proses penyelesaian pernikahan 
yang tidak tercatat di atas dengan one day service dalam isbat nikah terpadu bagi penduduk marjinal menjadi penting.

\section{B. Hasil dan Pembahasan}

1. Faktor-Faktor Penyebab Pernikahan Tidak Tercatat.

Ada beberapa faktor yang menyebabkan pernikahan tidak tercatat di sebagian masyarakat yang ada di Kecamatan Paliyan di antaranya, ditemukan fakta bahwa pada waktu pernikahan ada sebagian masyarakat yang tidak mempersiapkan persyaratan nikah dengan baik, bahkan ada yang sama sekali tidak membawa persyaratan nikah, tetapi mereka minta dinikahkan oleh petugas (Pegawai Pencatat Nikah) yang sedang menikahkan tetangga atau peristiwa yang berdekatan dengan rumahnya, dengan catatan persyaratan akan dipenuhi setelah akad nikah dilaksanakan. ${ }^{6}$

Namun faktanya setelah pernikahan terjadi, persyaratan tidak kunjung dipenuhi dan bahkan dianggap kurang penting oleh sebagian masyarakat, sehingga buku nikah tidak bisa diterbitkan oleh Kantor Urusan Agama karena syarat dan bukti pencatatan tidak lengkap atau bahkan tidak ada sama sekali. Peristiwa seperti ini biasanya disebut belo nikah. Pernikahan seperti ini tidak segera di tindak lanjuti oleh pasangan suami isteri karena mereka tidak menemukan kendala dalam mengurus persuratan dan data-data kependudukan lainnya karena kondisi administrasi saat itu belum setertib sekarang. ${ }^{7}$

Jauhnya jarak dan sulitnya medan juga ikut memperparah dan memperbanyak peristiwa pernikahan dengan model belo nikah ini. Pada masa itu pernikahan yang dilaksanakan di luar balai nikah (nikah bedol) ada yang jaraknya sangat jauh dari Kantor (Balai Nikah) dengan kondisi jalan yang belum baik dan berbukit, sementara petugas (Penghulu) harus jalan kaki menuju lokasi pernikahan yang jaraknya puluhan kilometer. Peristiwa seperti ini (belo nikah) saat itu dianggap wajar. ${ }^{8}$ Persyaratan nikah yang tidak segera diselesaikan menyulitkan petugas untuk melakukan 
pencatatan dan bahkan menyebabkan tidak tercatatnya peristiwa nikah tersebut di akta nikah yang ada di Kantor Urusan Agama. ${ }^{9}$

Di sisi lain ditemukan adanya peristiwa pernikahan yang dilakukan di depan jenazah. Hal ini terjadi karena ada kepercayaan di masyarakat yang ada di Kecamatan Paliyan khususnya dan Kabupaten Gunungkidul pada umumnya, apabila ada salah satu keluarga dari calon mempelai meninggal dunia, sedangkan kedunya sudah menjalin hubungan yang serius dan sudah sampai tahap khitbah ${ }^{10}$, maka keduanya harus dinikahkan di depan jenazah sebelum jenazah dimakamkan. Kalau hal ini tidak dilakukan maka kedua mempelai akan mengalami musibah atau kesialan-kesialan akan datang silih berganti, dan bahkan ada yang beranggapan pernikahannya tidak akan langgeng. Mitos ini sedemikian kuat di masyarakat sehingga mau tidak mau kedua mempelai harus dinikahkan untuk menghindari berbagai macam musibah dan kesialan yang akan terjadi (menurut keyakinan masyarakat) walaupun persyaratan nikah belum lengkap dan bahkan kadang belum ada persyaratan sama sekali. Adat dan keyakinan yang demikian ini dinamakan kerubuhan gunung. ${ }^{11}$

Setelah terjadinya pernikahan, konsentrasi keluarga tertuju pada pemakaman jenazah dan kegiatan-kegiatan lain yang terkait dengan kematian seseorang seperti tujuh hari (mitung dino) ${ }^{12}$ dengan berbagai persiapannya. Akibatnya pengurusan surat-surat yang menjadi syarat pernikahan menjadi terabaikan bahkan terlupakan, karena mempelai pun seungguhnya juga belum siap menikah pada situasi yang demikian itu. Di sisi lain, mempelai juga tidak menemukan kendala-kendala administrasi maupun kendala-kendala hukum saat itu, karena kondisi adminitrasi kependudukan dan kepemerintahan belum setertib seperti sekarang. Dengan demikian pernikahan ini menjadi tidak tercatat dalam akta nikah yang ada di Kantor Urusan Agama. ${ }^{13}$

Rendahnya kesadaran masyarakat akan pentingnya pencatatan peristiwa nikah ini disebakan oleh longgarnya administrasi 
kepemerintahan saat itu. ${ }^{14}$ Masyarakat yang tidak mempunyai buku nikah tidak menemukan kendala yang berarti dan mereka beranggapan bahwa pencatatan itu urusan negara dan bukan merupakan bagian dari kepentingan mereka sebagai masyarakat. Kesadaran yang demikian memang tidak bisa disalahkan karena kondisi dan situasi saat itu masih jauh dari ketertiban administrasi. ${ }^{15}$

Keteledoran oknum petugas (penghulu) juga ikut memberikan warna pada tidak tercatatnya peristiwa pernikahan yang terjadi saat itu. Hal ini terjadi karena kesadaran akan resiko hukum dan kesadaran penting administrasi pencatatan nikah masih rendah. Di samping itu, pengawasan dari atasan langsung kurang maksimal, karena jauhnya jarak dan sulitnya medan. Ada wilayah Kecamatan Paliyan yang jauh dari Balai Nikah dan pencatatan nikahnya diserahkan pada kantor perwakilan. Kewenangan untuk memberikan pelayanan nikah dan melaporkan peristiwa nikah Kantor perwakilan ke Kantor Urusan Agama Kecamatan Paliyan sebagai Kantor induk ini menjadi salah satu sebab longgarnya pengawasan penghulu. ${ }^{16}$

Pembagian tugas pernikahan bedol yang tidak adil oleh Kepala (Pegawai Pencatat Nikah) juga ikut mewarnai potret buruk dalam administrasi pencatatan nikah ini. Hal ini menyebabkan tidak semua peristiwa nikah yang terjadi dicatat dan dilaporkan oleh Penghulu pada pimpinan (PPN), karena mereka mempunyai anggapan kalau semua dilaporkan pada pimpinan akan terjadi pembagian yang tidak adil. Ujung dari semua ini adalah adanya motif ekonomi dalam pelayanan nikah. Itulah beberapa faktor yang menyebabkan pernikahan tidak tercatat di sebagian masyarakat yang ada di Kecamatan Paliyan. ${ }^{17}$

Perkawinan dapat dikatakan sebagai perbuatan hukum apabila dilakukan menurut ketentuan hukum yang berlaku dalam hukum positif. Hukum yang mengatur mengenai tata cara perkawinan di antaranya Undang-undang Nomor 1 Tahun 1974 tentang Perkawinan dan Peraturan Pemerintah Nomor 9 Tahun 1975 tentang Pelaksanaan 
Undang-Undang Nomor 1 tentang Perkawinan. Dengan begitu, perkawinan ini akan mempunyai akibat hukum yaitu akibat yang mempunyai hak mendapatkan pengakuan dan perlindungan hukum. Dalam Pasal 2 ayat (1) Undang-Undang Nomor 1 Tahun 1974 tentang Perkawinan menentukan bahwa suatu perkawinan baru dapat dikatakan sebagai perkawinan yang sah menurut hukum apabila perkawinan itu dilakukan menurut masing-masing agama dan kepercayaannya dan ayat (2) menentukan tiap-tiap perkawinan dicatat menurut peraturan perundang-undangan yang berlaku. ${ }^{18}$

Di antara tujuan pencatatan perkawinan dalam Pasal-Pasal tersebut di atas adalah untuk mewujudkan ketertiban perkawinan dalam masyarakat. Pencatatan perkawinan juga berfungsi untuk melindungi martabat dan kesucian perkawinan, dan lebih khusus lagi untuk melindungi kaum wanita dalam kehidupan rumah tangga. Dengan pencatatan perkawinan perselisihan di antara suami isteri sebagai akibat dari ketidak konsistenan salah satu pihak untuk mewujudkan tujuan perkawinan dapat melakukan upaya hukum guna mempertahankan dan memperoleh hak masing-masing, karena dengan catatan pernikahan tersebut suami-isteri memiliki bukti autentik atas perbuatan hukum yang telah mereka lakukan. ${ }^{19}$

Pencatatan perkawinan diwajibkan oleh peraturan perundangundangan di Indonesia dan dijadikan sebagai satu-satunya alat bukti yuridis formal bagi adanya perkawinan. Namun, di sisi lain perundangundangan membuka pintu bagi mereka yang tidak dapat membuktikan adanya perkawinan mereka dengan alat bukti akta nikah untuk menyelesaikan persoalan mereka melalui instansi pemerintah yang resmi yaitu Pengadilan Agama dengan dibukanya jalan bagi penetapan nikah mereka (isbat nikah). Hal ini sesuai dalam Kompilasi Hukum Islam Pasal 7 Ayat (2) yang berbunyi: “Dalam hal perkawinan tidak dapat dibuktikan dengan akta nikah, dapat diajukan isbat nikahnya ke Pengadilan Agama". ${ }^{20}$ 
2. Peran Penghulu dalam Menyelesaikan Pernikahan Tidak Tercatat.

Isbat nikah adalah salah satu solusi untuk mendapatkan buku nikah bagi pasangan yang pernikahannya tidak tercatat. Isbat nikah adalah penetapan atas perkawinan seorang pria dengan seorang wanita sebagai suami istri yang sudah dilaksanakan sesuai dengan ketentuan agama Islam ( sudah terpenuhinya syarat dan rukun nikah). Tetapi pernikahan yang terjadi pada masa lampau ini tidak dicatatkan pada pejabat yang berwenang, dalam hal ini Pegawai Pencatat Nikah (PPN) Kantor Urusan Agama. $^{21}$

Pada dasarnya kewenangan perkara isbat nikah bagi Pengadilan Agama dalam sejarahnya adalah diperuntukkan bagi mereka yang melakukan perkawinan di bawah tangan sebelum diberlakukannya Undang-Undang Nomor 1 tahun 1974 tentang Perkawinan. Jo. Peraturan Pemerintah No. 9 Tahun 1975 (penjelasan Pasal 49 ayat (2), Jo. Pasal 64 UU No. 1 tahun 1974). Namun kewenangan ini berkembang dan diperluas dengan dipakainya ketentuan Kompilasi Hukum Islam (KHI) Pasal 7 ayat 2 dan 3, dalam ayat (2) disebutkan bahwa dalam hal perkawinan tidak dapat dibuktikan dengan akad nikah, dapat diajukan isbat nikahnya ke Pengadilan Agama. ${ }^{22}$

Sedangkan pada Pasal 7 ayat (3) Kompilasi Hukum Islam disebutkan bahwa isbat nikah yang dapat diajukan ke Pengadilan Agama terbatas mengenai hal-hal yang berkenaan dengan: a) Adanya perkawinan dalam rangka penyelesaian perceraian, b) hilangnya akta nikah, c) adanya keraguan tentang sah atau tidaknya salah satu syarat perkawinan, d) adanya perkawinan yang terjadi sebelum berlakunay Undang-undang No 1 Tahun 1974, dan e) adanya perkawinan yang dilakukan oleh mereka yang tidak mempunyai halangan perkawinan menurut Undang-undang Nomor 1 Tahun 1974. ${ }^{23}$

Dengan demikian mengenai kompetensi absolut tentang isbat nikah sebagai perkara voluntair ini tidak bisa dianalogikan (diqiyaskan) dengan perkara pembatalan perkawinan, perceraian, atau poligami. 
Prinsipnya, pengadilan tidak mencari-cari perkara tetapi perkara itu telah menjadi kewenangannya karena telah diberikan oleh UndangUndang. Menurut Wasit Aulawi, perkara isbat nikah dapat dilayani oleh Pengadilan Agama. ${ }^{24}$

Dalam menyelesaikan isbat nikah di atas, penghulu melakukan koordinasi, ${ }^{25}$ kolaborasi ${ }^{26}$ dan sinergi ${ }^{27}$ untuk memadukan, menyelaraskan dan menyamakan persepsi dengan stakeholder yang ada, ${ }^{28}$ baik stakeholder dalam kelompok promotor, latens, defenders maupun apathetics. Untuk mensukseskan program one day service dalam isbat nikah terpadu bagi penduduk marjinal penghulu mengerahkan daya dan upaya untuk mengelola dengan baik terhadap stakeholder dalam kelompok promotors karena mereka mempunyai kepentingan besar dan kekuatan untuk membantu menggerakan serta mensukseskan program one day service ini. Adapun stakeholder dalam kelompok promotors adalah sebagai berikut: ${ }^{29}$

a. Pengadilan Agama Wonosari yang berperan mengesahkan pernikahan masyarakatmarjinalyang tidak tercatatperkawinannya dengan sidang isbat nikah secara keliling di desa sasaran program one day service untuk memudahkan dan mendekatkan layanan.

b. Kantor Kementerian Agama KabupatenGunungkidul yang dalam hal ini diwakili oleh Kantor Urusan Agama Kecamatan Paliyan yang berperan mencatat pernikahan masyarakat marjinal yang telah disahkan oleh Pengadilan Agama Wonosari.

c. Dinas Kependudukan dan Catatan Sipil Kabupaten Gunungkidul yang berperan menerbitkan akta kelahiran anak-anak masyarakat marjinal yang telah disahkan dan dicatatkan perkawinanya.

d. Biro Tata Pemerintahan Setda Daerah Istimewa Yogyakarta sebagai penanggung jawab dana kegiatan one day servise dalam isbat nikah terpadu bagi penduduk marjinal ini.

Penghulu tetap menjaga komunikasi yang efektif terhadap stakeholder dalam kelompok latens agar meraka tidak kehilangan minat terhadap 
proyek perubahan yang sedang dilaksanakan, karena sesungguhnya mereka memiliki kekuatan besar untuk mempengaruhi proyek perubahan jika meraka tertarik, walaupun dalam hal ini mereka tidak mempunyai kepentingan khusus. Adapun stakeholder dalam kelompok latens adalah Bupati Gunungkidul, Camat Paliyan, Kepala Desa se-Kecamatan Paliyan dan Dukuh se-Kecamatan Paliyan. ${ }^{30}$

Stakeholder dalam kelompok defenders, yaitu mereka yang memeliki kepentingan pribadi dan dapat menyuarakan dukungannya dalam komunitas, tetapi kekuatannya kecil. Mereka harus terus diberikan informasi untuk menjaga ketertarikan terhadap one day service dalam isbat nikah terpadu bagi penduduk marjinal di Kecamatan Paliyan. Stakeholder dalam kelompok defenders di antaranya Kepala Seksi Pemerintahan Kecamatan, Kepala Seksi Pelayanan di Desa, Ketua Rukun Tetangga (RT) dan masyarakat marjinal. ${ }^{31}$

Stakeholder dalam kelompok aphatetic, yaitu mereka yang tidak mempunyai kepentingan maupun kekuatan bahkan mungkin tidak mengetahui adanya proyek perubahan tetap harus dalam pantauan tanpa memberikan beban yang memberatkan agar dapat membantu saat dibutuhkan. Stakeholder dalam kelompok apathetics di antaranya tokoh agama, tokoh masyarakat, Penyuluh Agama Honorer, dan Pendamping Keluarga Harapan. ${ }^{32}$

Hasil dari koordinasi, kolaborasi dan sinergi antara penghulu dengan stakeholder terkait adalah sebuah kesepakatan yang diwujudkan dalam Memorandum of Understanding (MoU) one day serice dalam isbat nikah terpadu bagi penduduk marjinal yang dijadikan acuan dalam pelaksanaan kegiatan.

3. Persiapan One day service dalam Isbat Nikah Terpadu bagi Penduduk Marjinal di Kecamatan Paliyan.

Untuk mendapatkan dukungan yang lebih besar, one day service di awali dengan sosialisasi yang di laksanakan secara berjenjang, mulai dari tingkat kabupaten, kecamatan dan diakhiri di desa yang menjadi 
sasaran program one day service. ${ }^{33}$ Untuk menemukan masyarakat marjinal yang tidak mempunyai buku nikah dilakukan pendataan. Untuk memudahkan pencarian data di lapangan, koordinasi dan sinergi dengan dukuh sebagai pemangku wilayah terbawah di desa menjadi sangat penting. Selanjutnya dukuh akan berkoordinasi dengan Pendamping Keluarga Harapan (PKH) untuk mengetahui data penduduk marjinal yang pernikahannya tidak tercatat. ${ }^{34}$ Berdasarkan pendataan tersebut diketahui bahwa di Kecamatan Paliyan terdapat 9,27 persen keluarga yang tidak mempunyai buku nikah yang tersebar di semua desa yang ada di Kecamatan Paliyan. ${ }^{35}$

Untuk meyakinkan data yang diperoleh telah memenuhi syarat sebagai data yang akurat dan tidak cacat diperlukan verifikasi. Verifikasi merupakan langkah pemeriksaan terhadap data yang telah diperoleh dalam pengumpulan data. Setelah verifikasi data dilanjutkan dengan seleksi data. Seleksi data bertujuan untuk memilih data yang benar untuk diolah lebih lanjut, dan menyisihkan data yang tidak benar. ${ }^{36}$

Berdasarkan verifikasi dan seleksi data perkawinan yang tidak tercartat di Kecamatan Paliyan diketahui 62,66 persen perkawinan yang tidak tercatat berasal dari penduduk marjinal. Mereka inilah yang dijadikan sebagai sasaran one day service dalam isbat nikah terpadu bagi penduduk marjinal di kecamatan Paliyan. Sementara 37,34 persen keluarga yag perkawinannya tidak tercatat bukan berasal dari keluarga marjinal, sehingga diharapkan dapat memproses isbat nikah secara mandiri ke Pengadilan Agama dan tidak mengikuti program one day service dalam isbat nikah terpadu bagi penduduk marjinal ini.

Verifikasi dan seleksi pada tahap ini tidaklah terlalu ketat ${ }^{37}$ karena menurut Surat Edaran Mahkamah Agung Nomor 3 Tahun 2014 dalam pelayanan isbat nikah terpadu lebih pada pendekatan kemanusiaan ${ }^{38}$. Dalam kasus seperti ini kriteria penduduk marjinal diperlonggar dan tidak hanya mengacu data yang ada dalam Pendamping Keluarga Harapan, tetapi sesuai data riel yang ditemukan di lapangan. 
Berdasarkan Perma Nomor 1 Tahun 2015 tentang Pelayanan Terpadu Sidang Keliling Pengadian Negeri dan Pengadilan Agama/Mahkamah Syaríyah dalam Rangka Penerbitan Akta Perkawinan, Buku Nikah dan Akta Kelahiran, sidang isbat nikah dapat dilaksanakan dengan hakim tunggal dan hanya diperuntukan dalam perkara voluntair. ${ }^{39}$ Penduduk marjinal yang tidak mempunyai buku nikah di atas harus diverifikasi satu persatu untuk menemukan keluarga yang suami dan isterinya masih lengkap . ${ }^{40}$ Berdasarkan verifikasi di atas, dapat diketahui bahwa tidak semua penduduk marjinal yang tidak mempunyai buku nikah yang ada di Kecamatan Paliyan dapat dilayani pada one day service dalam isbat nikah terpadu bagi penduduk marjinal ini, karena hanya 89,40 persen yang pasangan suami isterinya masih lengkap, sedangkan 10,6 persen tidak dapat dilayani melalui one day service ini, karena salah satu pihak sudah meninggal dunia.

Untuk memastikan bahwa pernikahan penduduk marjinal di atas tidak tercatat, maka dilakukan verifikasi di desa yang dilaksanakan oleh Kepala Seksi Pelayanan terhadap register nikah yang ada di desa (N10) ${ }^{41}$ dan verifikasi oleh penghulu dengan register nikah (akta nikah) yang ada di Kantor Urusan Agama Kecamatan. ${ }^{42}$ Berdasarkan verifikasi tersebut ditemukan data sebagai berikut:

a. Ditemukan 83 peristiwa nikah dihadiri oleh penghulu dan tercatat di register nikah yang ada di Desa (N10) maupun register nikah yang ada di Kantor Urusan Agama Kecamatan (Akta nikah), tetapi yang bersangkutan tidak mempunyai buku nikah (tidak pernah di beri buku nikah). Kasus ini tidak termasuk dalam program pelayanan one day service dalam isbat nikah terpadu bagi penduduk marjinal ini, karena solusinya cukup diselesaikan di Kantor Urusan Agama Kecamatan dengan memberi Surat Keterangan Nikah atau Duplikat Nikah dengan persyaratan yang telah ditentukan dalam perundang-undangan yang berlaku.

b. Ditemukan 254 peristiwa nikah dihadiri oleh Penghulu dan tercatat di register nikah yang ada di Desa (N10) tetapi tidak 
ditemukan catatan pernikahannya di register yang ada di Kantor Urusan Agama Kecamatan, sehingga yang bersangkutan tidak mempunyai buku nikah. Data yang seperti inilah yang merupakan prioritas utama untuk diselesaikan melalui pelayanan one day service dalam isbat nikah terpadu bagi penduduk marjinal.

c. Ditemukan 233 peristiwa nikah dihadiri oleh Penghulu, tetapi catatan pernikahannya tidak ditemukan dalam register nikah yang ada di desa (N10) dan register nikah yang ada di Kantor Urusan Agama Kecamatan (Akta nikah) sehingga yang bersangkutan tidak mempunyai buku nikah. Inilah prioritas kedua dalam pelayanan one day service dalam isbat nikah terpadu bagi penduduk marjinal.

d. Ditemukan 91 peristiwa nikah tidak dihadiri oleh Penghulu tetapi diduga pernikahnnya sah karena dilaksanakan oleh tokoh agama (kyai) sehingga catatan pernikahannya tidak ditemukan dalam register nikah yang ada di Desa (N10) maupun register nikah yang ada di Kantor Urusan Agama Kecamatan (Akta nikah). Penduduk yang termasuk dalam kasus seperti ini, tidak mendapat pelayanan one day service dalam isbat nikah terpadu bagi penduduk marjinal, karena mereka dengan sengaja tidak mencatatkan pernikhannya pada pejabat yang wenang (PPN). Untuk menyelesaikan kasus ini, yang bersangkutan dapat mengajukan isbat nikah ke Pengadilan Agama secara mandiri.

e. Ditemukan 18 keluarga yang tidak menikah tetapi hidup dalam satu rumah (kumpul kebo) sehingga catatan pernikahannya tidak ditemukan dalam register nikah yang ada di Desa maupun register nikah yang ada di Kantor Urusan Agama Kecamatan (Akta nikah). Kasus ini dapat diselesaikan dengan pernikahan baru kalau yang bersangkutan memenuhi syarat untuk dinikahkan dan bagi yang tidak memenuhi syarat dapat diselesaikan secara adat dan kearifan lokal yang berlaku di wilayah tersebut. 
Untuk menyamakan, meyelaraskan dan menyesuaikan semua kegiatan pelayanan dan data peserta isbat nikah diperlukan singkronisasi dari keempat pelaksana program one day service dalam isbat nikah terpadu bagi penduduk marjinal, yaitu Biro Tata Pemerintahan Setda Daerah Istimewa Yogyakarta, Pengadilan Agama Wonosari, Kantor Urusan Agama Kecamatan Paliyan dan Dinas Kependudukan dan Catatan Sipil Kabupaten Gunungkidul. ${ }^{43}$

\section{Pelaksanaan One day service}

Setelah semua proses persiapan one day service dalam isbat nikah terpadu bagi penduduk marjinal selesai, ditetapkanlah waktu dan tempat pelaksanaan one day service. Pelayanan dilaksanakan di desa dengan sidang keliling ${ }^{44}$ untuk memudahkan dan mendekatkan pelayanan kepada msyarakat. ${ }^{45}$

One day service dalam isbat nikah terpadu bagi penduduk marjinal ini merupakan inovasi layanan yang diprakarsai oleh penghulu dan merupakan layanan unggulan karena masyarakat tidak dipungut biaya (gratis), pelaksanaan sidang di lakukan keliling (didekatkan dengan masyarakat) dan diselesaikan dalam waktu satu hari. Artinya masyarakat dalam sehari mendapatkan putusan penetapan nikah dari Pengadilan Agama, buku nikah dari Kantor Urusan Agama dan akte kelahiran dari Dinas Kependudukan dan Catatan Sipil bagi anak-anak dari hasil pernikahan yang diisbatkan. ${ }^{46}$

One day service dalam isbat nikah terpadu bagi penduduk marjinal dilaksanakan dalam empat tahap. Tahap pertama adalah sidang isbat nikah yang dilaksanakan oleh Pengadilan Agama Wonosari. Mekanisme sidang sepenuhnya berada pada kewenangan Pengadilan Agama melalui majlis hakim atau hakim tunggal yang menyidangkan perkara tersebut. Berhasil atau tidaknya sidang isbat nikah merupakan kewenangan mutlak hakim dengan mempertimbangkan fakta, saksi, dan bukti yang ditemukan di persidangan. Untuk mempercepat jalannya sidang, maka pada one day service dalam isbat nikah terpadu bagi penduduk 
marjinal ini dibuka beberapa ruang sidang sesuai kebutuhan dengan mempertimbangkan jumlah peserta sidang. ${ }^{47}$

Untuk lebih mengefektifkan dan mengefisienkan pelayanan, tim kerja dari Pengadilan Agama dibagi ke dalam empat kelompok. Tim pertama terdari dari staf administrasi yang bertugas meregristasi peserta dan menyiapakan peserta untuk sidang. Tim yang kedua terdiri dari hakim dan panitera yang bertugas menyidangkan perkara. Tim yang ketiga terdiri dari operator yang bertugas mencetak hasil penetapan yang telah diputuskan oleh hakim dan tim yang keempat adalah korektor, yang terdiri dari hakim dan panitera yang bertugas mengoreksi hasil penetapan yang telah dicetak oleh operator. Setelah penetapan isbat nikah ini dinyatakan benar, barulah diserahkan ke Kantor Urusan Agama untuk dicatatkan pernikahannya sesuai dengan hasil penetapan. ${ }^{48}$

Tahap kedua adalah pencatatan nikah oleh Kantor Urusan Agama Kecamatan yang mewilayahi terjadinya akad nikah. Untuk mempercepat pelayanan tim dari Kantor Urusan Agama Kecamatan dibagi ke dalam empat kelompok. Tim pertama terdiri dari penghulu yang bertugas memeriksa pasangan yang telah diisbatkan pernikahannya guna mendapatkan data yang lengkap dan akurat. Tim kedua teridiri dari operator yang bertugas mencetak buku nikah setelah dinyatakan lengkap dan akurat oleh Penghulu. Tim ketiga terdiri dari staf administrasi yang bertugas menyelesaikan administrasi pencatatan dan buku nikah dan tim keempat terdiri dari staf administrasi yang bertugas melegalisir buku nikah dan menyampaikannya ke petugas dari Dinas Kependudukan dan Catatan Sipil Kabupaten Gunungkidul. ${ }^{49}$

Tahap ketiga adalah penerbitan akta kelahiran bagi anak-anak yang dihasilkan dari pernikahan yang diisbatkan oleh Pengadilan Agama. Untuk mempercepat pelayanan tim dari Dinas Kependudukan dan Catatan Sipil di bagi ke dalam tiga kelompok. Tim yang pertama terdiri dari tim verifikator yang bertugas memverifikasi persyaratan administrasi penerbitan akta kelahiran yang diajukan oleh pemohon. Tim yang 
kedua terdiri dari operator yang bertugas mencetak akta kelahiran yang sudah dinyatakan lengkap persyaratan administrasinya. Dan tim yang ketiga bertugas mengoreksi dan menyerahkan akta kelahiran kepada pemohon. ${ }^{50}$

Tahap keempat adalah acara seremonial penyerahan output dari pelayanan one day service dalam isbat nikah terpadu bagi penduduk marjinal, yaitu penetapan isbat nikah yang diserahkan oleh Ketua Pengadilan Agama Wonosari, buku nikah yang diserahkan oleh Kepala Kantor Urusan Agama Kecamatan Paliyan dan Akta kelahiran yang diserahkan oleh Kepala Dinas Kependudukan dan Catatan Sipil Kabupaten Gunungkidul. Acara ini diawali oleh sambutan dan pengarahan dari Kepala Biro Tata Pemerintahan Setda Daerah Istimewa Yogyakarta dan Sambutan oleh Bupati Gunungkidul serta-tamu-tamu penting yang hadir pada acara tersebut. ${ }^{51}$

Kegiatan pelayanan one day service dalam isbat nikah terpadu bagi penduduk marjinal ini sudah dilaksanakan sejak tahun 2015 sampai sekarang. Setiap tahun kegiatan ini dilaksnakan dua sampai tiga kali pelayanan sesuai dengan jumlah peserta dan kuota yang ditetapkan oleh Biro Tata Pemerintahan Setda Daerah Istimewa Yogyakarta berdasarkan data yang telah di verifikasi dari Kantor Urusan Agama Kecamatan.

Pengadilan Agama Wonosari telah berhasil menyidangkan perkara isbat nikah bagi penduduk marjinal sebanyak 497 perkara pada kurun waktu 4 tahun terakhir. Pada tahun 2019 direncanakan 100 perkara yang terbagi dalam tiga tahap, tahap pertama di Desa Sodo sebanyak 35 perkara, tahap kedua di Desa Ngoro sebanyak 35 perkara dan dan tahap ke tiga di Desa Kanigoro sebanyak 30 perkara.

Kantor Urusan Agama Kecamatan Paliyan pada pelayanan one day service dalam isbat nikah terpadu bagi pebduduk marjinal telah berhasil mencatat pernikahan penduduk marjinal sebanyak 494 perkara pada kurun waktu 4 tahun terakhir. Pada tahun 2019 direncanakan 100 pasang 
yang terbagi dalam tiga tahap, tahap pertama di Desa Sodo sebanyak 35 pasang, tahap kedua di Desa Ngoro sebanyak 35 pasang dan dan tahap ke tiga di Desa Kanigoro sebanyak 30 pasang.

Dinas Kependudukan dan Catatan Sipil Kabupaten Gunungkidul pada pelayanan one day service dalam isbat nikah terpadu bagi pebduduk marjinal telah berhasil menerbitkan akta kelahiran sebanyak 414 akta pada kurun waktu 4 tahun terakhir, dan pada tahun 2019 direncanakan 150 akta kelahiran yang terbagi dalam tiga tahap, tahap pertama di Desa Sodo sebanyak 50 akta kelahiran, tahap kedua di Desa Ngloro sebanyak 50 akta kelahiran dan dan tahap ke tiga di Desa Kanigoro sebanyak 50 akta kelahiran.

One day service dalam isbat nikah terpadu bagi penduduk marjinal ini banyak mendapatkan apresisi dari banyak pihak, baik tingkat nasional maupun internasional, di antaranya apresiasi disampaikan oleh Dirjen Badilag dari Pengadilan Agama, Dirjen Pencatatan Sipil dari Kementerian Dalam Negeri, dan bahkan kegiatan ini mendapatkan apresiasi dari Australia Indonsia Partnership for Justice (AIPJ) sebuah Lembaga Swadaya Masyarakat dari Australia yang bergerak di bidang keadilan terhadap kelompok-kelompok marjinal.

\section{Kesimpulan dan Saran}

Kesimpulan

1. Faktor-faktor penyebab perkawinan tidak tercatat di antaranya, belo nikah, kerubuhan gunung, kondisi wilayah yang jauh dan berbukit, kesadaran masyarakat rendah dan kurangnya pengawasan.

2. Penghulu meyakinkan pentingnya pencatatan nikah kepada masyarakat dan stake holder terkait. Penghulu melakukan koordinasi, kolaborasi dan sinergi dengan stakeholder tekait secara intensif dan berhasil menyepakati model pelayanan yang murah, 
mudah dan cepat. Kesepakatan tersebut dituangkan dalam Memorandum of Undertanding pada one day service dalam isbat nikah terpadu bagi penduduk marjinal.

3. One day service dalam isbat nikah terpadu bagi penduduk marjinal merupakan solusi hukum atas permasalahan tidak tercatatnya perkawinan sebagian masyarakat marjinal yang ada di Kecamatan Paliyan. Proses one day service diawali dengan pengesahan nikah di Pengadilan Agama, pencatatan nikah di Kantor Urusan Agama dan penerbitan akta kelahiran di Dukcapil.

\section{Saran}

1. One day service dalam isbat nikah terpadu bagi penduduk marjinal ini diharapkan dapat terus dipertahankan dan ditingkatkan pelayanannya, sehingga masyarakat merasa senang dan puas dengan pelayanan yang diberikan oleh pemerintah dengat cepat, mudah dan murah bahkan gratis.

2. Semua stakeholder hendaknya mengurangi ego sektoralnya untuk melakukan koordinasi, sinergi dan kolaborasi guna menemukan inovasi pelayanan publik yang lebih baik dan terukur dalam menyelesaikan persoalan-persoalan yang dihapai oleh masyarakat, khususnya masyarakat marjinal yang memerlukan perhatian lebih dari pemerintah. 


\section{Daftar Pustaka}

Abdul Sabaruddin. 2014, Manajemen Kolaborasi dalam Pelayanan Publik, Solo: Graha Ilmu.

Alcock, P. 1993, Understanding Proverty, London: Mac Millan Press Ltd.

Ali, A. Halim. 1990, Melukut Kota ;Pengalaman sosial golongan miskin di Sandakan, Bangi: Penerbit Universiti Kebangsaan Malaysia.

Faisal, Sanapiah. 2008, Format-format Penelitian Sosial, Jakarta: PT Rajawali Press.

Hasan, Iqbal. 2002, Analisis Data Penelitian Dengan Statistik, Jakarta: Bumi Aksara.

Kasmir. 2010, Manajemen Perbankan, Jakarta: PT Raja Grafindo Persada.

Komarudin. 2013, Manajemen Kantor Teori dan Praktek, Bandung: Triyenda Karya.

M. Zuhdi Muhdlor. 1995. Memahami Hukum Perkawinan (Nikah, Talak, Cerai dan Rujuk) Menurut Hukum Islam, UU No.1 Tahun 1974, UU No.7 Tahun 1989 dan KHI di Indonesia. Cet-II. , Bandung: Al-Bayan, 1995.

Mahmudi. 2007, Manajemen Kinerja Sektor Publik, Yogyakarta : UPP STIM YKPN.

Mannan, Abdul. 2006, Aneka Masalah Hukum Perdata Islam di Indonesia ( Jakarta: Kencana.

Miles, B. Mathew dan Michael Huberman, 2009, Qualitative data Analysis, di terjemahkan oleh Tjetjep Rohendi Rohidi dengan judul Analisis Data Kualitatif Buku Sumber Tentang Metode-metode Baru, Cet. 1; Jakarta: UI Press.

Moenir. 2005, Manajemen Pelayanan Umum di Indonesia,Jakarta : Bumi 


\section{Aksara.}

Nasution, Khaeruddin. 2002, Status Wanita di Asia Tenggara: Studi Terhadap Perundang-Undangan Perkawinan Muslim Kontemporer di Indonesia dan Malaysia, Jakarta: INIS.

Nawawi, Hadari dan Murni Martini. 1996, Penelitian Terapan ( Cet. 2; Yogyakarta : Gajah Mada University Press.

Nur Djama'an, 2003, Fiqh Munakahat, Semarang: CV. Toha Putra.

Sedarmayanti, 2009, Manajemen Sumber Daya Manusia Reformasi Birokrasi dan Manajemen Pegawai Negeri Sipil ,Bandung : Mandar Maju.

Stephen R. Coveyd 2013, The 7 habits of highly effective people, diterjemahkan oleh Budijanto dengan judul, 7 kebiasaan manusia yang sangat efektif , Jakarta : Binarupa Aksara.

Sudarmayanti. 2007, Good Governance (Kepemerintahan Yang Baik) dan Good Corporate Governance (Tata Kelola Perusahaan Yang Baik), Bandung: CV. Bandar Maju.

Sutarto. 2008, Dasar-dasar Organisasi, Cet. 18, Yogyakarta: Gadjah Mada University Press.

Trikomo Y.Argo. 1999, Pemulung Jalanan Yogyakarta: Konstruksi Marjinalitas dan Perjuangan Hidup dalam Budaya- Budaya Dominan, Yogyakarta: Media Pressindo.

Victor Conde. 2004, A Handbook of International Human Rights Terminology, Lincoln : University of Nebraska.

W. Kumorotomo. 2004, Etika Administrasi Negara, Jakarta: Raja Grafindo Persada.

Zein, Satria Effendi M. 2005, Problematika Hukum Keluarga Islam Kontemporer, Jakarta: Kencana.

A. Wasit Aulawi, 1996, "Pernikahan Harus Melibatkan Orang Banyak", dalam Mimbar Hukum Aktualisasi Hukum Islam, No. 28 Tahun VII, 
Jakarta: Yayasan Al Hikmah.

Euis Nurlaelawati dan Alimin Mesra, 2011, "Potret Administrasi Keperdataan Islam di Indonesia", Laporan Penelitian, Lembaga Penelitian, UIN Jakarta.

Euis Nurlaelawati, 2013, "Pernikahan Tanpa Pencatatan: Isbat Nikah Sebuah Solusi?", JurnalMusâwa, Vol. 12 Nomor 2.

Khairuddin Julianda, 2017, "Pelaksanaan Isbat Nikah Keliling dan Dampaknya terhadap Ketertiban Pencatatan Nikah" (Studi Kasus di Kabupaten Bireuen)", Jurnal Hukum Keluarga dan Hukum Islam, Vol 1, Nomor 2.

Muchsin, 2008, “Problematika Perkawinan Tidak Tercatat dalam Pandangan Hukum Islam dan Hukum Positif",Materi Rakernas Perdata Agama Tahun 2008,Mahkamah Agung Republik Indonesia di Jakarta.

N. Asrul, 2013, "Implementasi Kebijakan Peraturan Daerah No 2 Tahun 2008 tentang Pembinaan Anak Jalanan, Gelandagan, Pengemis, dan Pengamen di Kota Makassar". Tesis Ijazah Fakultas Ilmu Sosial dan Ilmu Politik Universitas Hasanuddin Makassar.

Nasrudin Salim, 2003, “Isbat Nikah Dalam Kompilasi Hukum Islam (Tinjauan Yuridis, Filosofis dan Sosiologis)", dalam Mimbar Hukum Aktualisasi Hukum Islam, No. 62 Th. XIV , Jakarta: YayasanAl Hikmah.

Peraturan Mahkamah AgungNomor 1 Tahun 2015 tentang Pelayanan Terpadu Sidang Keliling Pengadilan Negeri dan Pengadilan Agamal Mahkamah Syar'iyah Dalam Rangka Penerbitan Akta Perkawinan, Buku Nikah, dan Akta Kelahiran.

Surat Edaran Mahkamah Agung Nomor 3 Tahun 2014 tentang Tata Cara Palayanan dan Pemeriksaan Perkara Voluntair Isbat Nikah dalam Pelayanan Terpadu. 
Umi Solikha dan Setiati Widihastuti, 2018, "Legalisasi Perkawinan Melalui Isbat Nikah Di Pengadilan Agama Wonosari Kabupaten Gunungkidul", Jurnal Pendidikan Kewaraganegaraan dan Hukum Volume 7 Nomor 4.

Aminah, S., dan Husni. (2007). “Kajian Pengembangan Kerangka Kerja Kolaborasi Evaluasi dengan Pendekatan Collaborative Business Process Management." Diakses dari http: //journal.uii. ac.id/index. php/Snati/ article/viewFile/1712/1493, tanggal 26 Juli 2019.

Jennifer Thomas, "Understanding Human Rights Protecting Human Rights to Benefit " di akses dari https://yali.state.gov/wp- content/ uploads/sites /4/2016/12/Protecting-Human-Rights-to-Benefit-AllDiscussion-Guide.pdf pada tanggal 18 Pebrua 2019.

Kementerian BPN/Bappenar, "Studi Kelompok Marjinal”, diakses dari http://psflibrary. org/catalog/repository/3739_SRS_PNPM\%20 Perdesaan_Kelompok\%20Marjinal.pdf, pada tanggal 7 Mei 2019, Sugiyono, verifikasi, diakses dari http://hasanthbisri.blogspot. co.id/2014/05/ verifikasi. html, pada tanggal 28 Pebruari 2019. 


\section{Endnotes}

1. Undang-Undang Nomor 1 Tahun 1974 tentang Perkawinan Pasal 1

2. Undang-Undang Nomor 1 Tahun 1974 tentang Perkawinan Pasal 2 ayat (2)

3. Instruksi Presiden Republik Indonesia Nomor 1 Tahun 1991 tentang Kompilasi Hukum Islam Pasal 6 ayat (1).

4. Khaeruddin Nasution, Status Wanita di Asia Tenggara: Studi Terhadap Perundang-Undangan Perkawinan Muslim Kontemporer di Indonesia dan Malaysia ( Jakarta: INIS, 2002), h. 32

5. Satria Effendi M. Zein, Problematika Hukum Keluarga Islam Kontemporer (Jakarta: Kencana, 2005), h. 33.

6. Wawancara dengan Wajiran, tanggal 4 Pebruari 2019 di Desa Karangasem.

7. Wawancara dengan Sarjono, tanggal 10 Pebruari 2019 di Desa Karangduwet.

8. Wawancara dengan Ngatijo, tanggal 12 Januari 2019 di Desa Kanigoro.

9. Wawancara dengan Wagiran, tanggal 11 Pebruari di Desa Mulusan.

10. Khitbah adalah mengungkapkan keinginan untuk mengawini seseorang perempuan tertentu, kemudian diumumkan kepada khalayak oleh pihak yang terlibat dalam proses pinangan baik sendiri atau secara bersama-sama.

11. Wawancara dengan Sumadiyanto, tangggal 23 Pebruari 2019 di Desa Sodo.

12. Mitung dino adalah selamatan setelah tujuh hari dari kematian seseorang yang dilaksanakan oleh keluarga yang di tinggal mati

13. Wawancara dengan Sumadiyanto, tanggal 20 Pebruari 2019 di Desa Sodo.

14. Muchsin, “ Problematika Perkawinan Tidak Tercatat dalam Pandangan Hukum Islam dan Hukum Positif",Materi Rakernas Perdata Agama Tahun 2008, Mahkamah Agung Republik Indonesia di Jakarta.

15. Wawancara dengan Agus Iswanjono, tanggal 4 Maret 2019 di Desa Krambilsawit.

16. Wawancara dengan Wagiran, tanggal 9 Maret di Pedukuhan Kenteng Desa Mulusan. 
17. Wawancara dengan H Wagiran, tanggal 6 Maret 2019 di Balai Desa Mulusan.

18. Undang-Undang Nomor 1 Tahun 1974 tentang Perkawinan Pasal 2.

19. M. Zuhdi Muhdlor. 1995. Memahami Hukum Perkawinan (Nikah, Talak, Cerai dan Rujuk) Menurut Hukum Islam, UU No.1 Tahun 1974, UU No.7 Tahun 1989 dan KHI di Indonesia. Cet-II. (Bandung: Al-Bayan, 1995), h. 69.

20. Satria Effendi M. Zein, Problematika Hukum Keluarga Islam Kontemporer (Jakarta: Kencana, 2005), h. 42.

21. Nasrudin Salim, "Isbat Nikah Dalam Kompilasi Hukum Islam (Tinjauan Yuridis, Filosofis dan Sosiologis)", dalam Mimbar Hukum Aktualisasi Hukum Islam, No. 62 Th. XIV (Jakarta: YayasanAl Hikmah, 2003), h. 70.

22. Ibid.

23. Instruksi Presiden Republik Indonesia Nomor 1 Tahun 1991 tentang Kompilasi Hukum Islam, Pasal 7 ayat (2).

24. A. Wasit Aulawi, "Pernikahan Harus Melibatkan Orang Banyak", dalam Mimbar Hukum Aktualisasi Hukum Islam, No. 28 Thn. VII (Jakarta: Yayasan Al Hikmah, 1996), h. 22.

25. Sedarmayanti, Manajemen Sumber Daya Manusia Reformasi Birokrasi dan Manajemen Pegawai Negeri Sipil (Bandung : Mandar Maju, 2009), h. 78.

26. Abdul Sabaruddin, Manajemen Kolaborasi dalam Pelayanan Publik (Solo: Graha Ilmu, 2014), h. 15.

27. Stephen R. Covey, The 7 habits of highly effective people, diterjemahkan oleh Budijanto dengan judul, 7 kebiasaan manusia yang sangat efektif (Jakarta : Binarupa Aksara, 2013), h. 78.

28. Aminah, S., dan Husni. (2007). “Kajian Pengembangan Kerangka Kerja Kolaborasi Evaluasi dengan Pendekatan Collaborative Business Process Management." Diakses dari http: //journal.uii. ac.id/index.php/Snati/article/ viewFile/1712/1493, tanggal 26 Juli 2019, jam 12.00.

29. Wawancara dengan Muhammad Syukur, tanggal 26 Pebruari 2019 di Kantor Urusan Agama Kecamatan Paliyan.

30. Wawancara dengan Marwotohadi, tanggal 26 Pebruari 2019 di Kecamatan Paliyan. 
31. Wawancara dengan Asih Surya, tanggal 26 Januari 2019 di Biro Tapem DI. Yogyakarta.

32. Wawancara dengan Marwotohadi, tanggal 26 Pebruari 2019 di Kecamatan Paliyan.

33. Rudi DS, "Memulai Program: Sosialisasi Awal yang Tepat Menentukan Langkah Selanjutnya" diakses dari https://www.masyarakatmandiri.co.id/ memulai-program-sosialisasi-awal-yang-tepat-menentukan-langkahselanjutnya/ pada tanggal 24 Pebruari 2019, jam 10.00.

34. Wawancara dengan Ashari Dwi Laksono, tanggal 13 Maret 2019 di Sekretarian PKH di Kecamatan Paliyan.

35. Wawancara dengan Wagiran, tanggal 12 Pebruari 2019 di Balai Desa Mulusan.

36. Sugiyono, verifikasi, diakses dari http://hasanthbisri.blogspot.co.id/2014/05/ verifikasi. html, pada tanggal 28 Pebruari 2019, jam 10.30.

37. Wawancara dengan Ashari Dwi Laksono, tanggal 13 Maret 2019 di Sekretarian PKH di Kecamatan Paliyan.

38. Surat Edaran Mahkamah Agung Nomor 3 Tahun 2014 tentang Tata Cara Palayanan dan Pemeriksaan Perkara Voluntair Isbat Nikah dalam Pelayanan Terpadu.

39. Wawancara dengan Ahmadi, tanggal 18 Maret 2019 di Pengadilan Agama Wonosari.

40. Wawancara dengan Muhammad Syukur, tanggal 20 Pebruari 2019 di Kantor Urusan Agama Kecamatan Paliyan.

41. Wawancara dengan Sumadiyanto, tanggal 12 Pebruari 2019 di Desa Sodo.

42. Wawancara dengan Wagiran, tanggal 15 Pebruari 2019 di Pedukuhan Kenteng.

43. Wawancara dengan Asih Surya tanggal 24 Juli di Balai Desa Sodo.

44. PERMA Nomor 1 Tahun 2015 tentang Pelayanan Terpadu Sidang Keliling Pengadilan Negeri dan Pengadilan Agama/Mahkamah Syar'iyah Dalam Rangka Penerbitan Akta Perkawinan, Buku Nikah, dan Akta Kelahiran. 
45. Wawancara dengan Bowo tanggal 2 April 2019 di Pengadilan Agama Wonosari.

46. Keputusan Ketua Muda Mahkamah Agung RI Urusan Lingkungan Pengadilan Agama Nomor : 01/Sk/Tuada-Ag/I/2013 Tentang Pedoman Sidang Keliling Di Lingkungan Peradilan Agama.

47. Wawancara dengan Ahmadi, tanggal 14 Maret 2019 di Pengadilan Agama Wonosari.

48. Ibid.

49. Wawancara dengan Muhammad Syukur, tanggal 20 Pebruari 2019 di Kantor Urusan Agama Kecamatan Paliyan.

50. Wawancara dengan Intoyo, tanggal 5 Maret 2019 di Dinas Kependudukan dan Catatan Sipil Kabupaten Gunungkidul.

51. Wawancara dengan Wahyu tanggal 6 Juni 2019 di Desa Sodo. 